\title{
MANAJEMEN PEMBELAJARAN BERBASIS DARING DALAM RANGKA MEMUTUS MATA RANTAI PENULARAN COVID-19 DI PERGURUAN TINGGI SWASTA LEMBAGA LAYANAN PERGURUAN TINGGI (LLDIKTI) WILAYAH VII
}

\author{
Suyono \\ Sekolah Tinggi Ilmu Ekonomi (STIE) IMBT Surabaya
}

\begin{abstract}
Abstrak
Salah satu usaha pemerintah untuk memutus mata rantai penularan Covid-19 adalah untuk mengurangi pengelompokan masa masyarakat, oleh karena itu sesuai dengan surat edaran menteri pendidikan dan kebudayaan republic indonesia nomor 3 tahun 2020 tentang pencegahan corona virus disease (Covid-19) pada satuan pendidikan. Sangat tepat dan harus didukung dan di sukseskan serta di publikasikan secara besar-besaran. Perguruan Tinggi Swasta Lembaga Layanan Pendidikan Tinggi (LLDIKTI) Wilayah VII, mempunya kewajiban untuk melaksanakan surat edaran tersebut diatas dengan cara melaksanakan rapat secara online terhadap Perguruan Tinggi di wilayahnya yang dilaksanakan pada hari/tanggal: Rabu, tanggal 8 April 2020. Adapun kegiatan yang lainnya yang telah dilaksanakan oleh LLDIKTI Wilayah VII terhadap PTS adalah memberikan hibauan agar PTS segera melaksanakan perkuliahan secara daring sesuai dengan surat edaran dari LLDIKTI Wilayah VII nomor: 578/Tahun 2020, tentang Pencegahan corona virus disease (Covid-19) (Surat edaran LLDIKTI Wilayah VII Nomor 578/TAHUN 2020 tanggal 16 Maret 2019). Adapaun fasilitas aplikasi converencing/metode-metode daring yang digunakan dalam pelaksanaan Study From Home (SFH) di PTS LLDIKTI Wilayah VII antara lain: SPAD, Zoom Meeting, Google Class Room, Email, Whatsapp, Telegram, Youtube. Sebagian besar PTS di lingkungan LLDIKTI Wilayah VII sudah melaksanakan Perkuliahan secara daring. Dengan adanya perkuliahan secara daring maka tidak terjadi pengelompokan masa yang sebagai mana biasanya dilakukan perkuliahan secara tatap muka, sehingga penularan Covid-19 dapat dicegah. Walaupun semua kegiatan itu dilakukan di rumah atau dengan metode daring sehingga program pemerintah memutus rantai penularan covid-19 bisa berjalan dengan baik dan sukses. Dan perkuliahan tetap berjalan sesuai dengan peraturan yang berlaku, yaitu tetap terpenuhi capaian pembelajana. Kampus tidak boleh tutup harus ada kegiatan, sedangkan Pimpinan PTS agar memfasilitasi kepentingan seluruh anggota civitas akademika Perguruan Tinggi tersebut.
\end{abstract}

Kata Kunci: Pembelajaran, Daring, Memutus rantai penularan Covid-19

\begin{abstract}
One of the government's efforts to break the chain of transmission of Covid-19 is to reduce community groupings, therefore according to the circular minister of education and culture of the Republic of Indonesia number 3 of 2020 concerning prevention of corona virus disease (Covid$19)$ in the education unit. Very appropriate and must be supported and succeeded and published on a large scale. The Higher Education Institution of Higher Education Institution (LLDIKTI) Region VII, has the obligation to respond to the circular above by holding an online meeting of the Higher Education Institutions in its area which is held on day / date: Wednesday, April 8, 2020. As for other activities that has been carried out by LLDIKTI Region VII to PTS is to give an appeal so that PTS immediately conducts lectures online in accordance with the circular letter from LLDIKTI Region VII number: 578/2020, concerning Prevention of corona virus disease (Covid-19). The application facilities for converencing / online methods used in the implementation of Study From Home (SFH) at PTS LLDIKTI Region VII include: SPAD, Zoom Meeting, Google Class Room, Email, Whatsapp, Telegram, Youtube. Most private universities in the LLDIKTI Region VII have already carried out online lectures. With online lectures, there
\end{abstract}


is no grouping which is usually done face-to-face lectures, so that Covid-19 transmission can be prevented. Although all these activities are carried out at home or by online methods so that the government program breaks the chain of transmission of Covid-19 to run properly. And lectures continue in accordance with applicable regulations, which is still fulfilled learning outcomes. Campus should not be closed there must be activities, while the PTS leadership to facilitate the interests of all members of the Higher Education community.

Keywords: Learning, Online, Breaking the chain of transmission of Covid-19

\section{PENDAHULUAN}

Seiring dengan berlakunya Peraturan Menteri Riset, Teknologi, dan Pendidikan Tinggi Nomor 15 Tahun 2018, terjadi transformasi organisasi dan tata kerja Kopertis Wilayah VII menjadi Lembaga Layanan Pendidikan Tinggi Wilayah VII dengan wilayah kerja di Provinsi Jawa Timur. LLDIKTI Wilayah VII Jawa Timur mempunyai tanggung jawab untuk mefasilitasi peningkatan mutu pada perguruan tinggi diwilayahnya. LLDIKTI Wilayah VII pada saat ini ada sebanyak 318 PTS terdiri dari: Universitas 91, Institut 18, Sekolah Tinggi 134, Akademi 56, Politeknik 11 dan Akademi Komunitas 8, Jumlah Prodi aktif sebanyak 2.101 prodi. Untuk Akreditasi Perguruan Tinggi (APT) sebagai berikut terakreditasi A sebanyak 7 PTS, akreditasi B: 95 PTS, Akreditasi C: 122 PTS , dan yang belum terakreditasi APTnya sebanyak: 94 PTS. Sedangkan data Program Studi sebagai berikut: Universitas yang terakreditasi sebanyak: 1.346 prodi dengan rincian Sbb: Akreditasi A: 133 Prodi, B: 751 prodi, akreditasi C: 462 prodi dan yang belum terakrediatsi sebanyak: 41 Prodi. Jadi total prodi untuk Universitas sebanyak: 1.387 prodi. Institut Prodi yang terakreditasi sebanyak 163 rincian sbb: akreditasi A sebanyak 18 prodi, akreditasi B sebanyak 145 prodi, yang belum akreditasi sebanyak 4 , total prodi sebanyak 167 . Sekolah Tinggi total jumlah prodi sebanyak: 154 prodi dengan rincian sbb: terakreditasi A sebanyak 3 prodi, B sebanyak 85 prodi dan $C$ sebanyak 55 prodi, sedangkan yang belum akreditasi sebanyak 11 prodi. Untuk Prodi PT yang berbentuk Akademi, Politeknik dan Akademi Komunitas sebanyak 2.101 prodi dengan rincian sbb: Akreditasi A sebanyak 18 prodi, akreditasi B sebanyak 238 prodi, akreditasi $\mathrm{C}$ sebanyak 200 prodi, yang belum terakreditasi sebanyak 28 prodi. Dosen dpk sebanyak 1164 dosen dan dosen tetap Yayasan sebanyak 18.668 dosen. Adapun menurut jabatan untuk dosen dpk sbb: Profesor sebanya 50 orang, Lektor Kepala sebanyak 127 orang, Lektor sebanyak 495, Asisten ahli sebanyak 465 orang dan yang belum punya jabatan akademik sebanyak 27 orang. Keadaan jabatan akademik untuk dosen tetap Yayasan sbb: Profesor sebanyak 68 orang, Lektor Kepala sebanyak 5344 orang, Lektor sebanyak 2453 orang, Asisten Ahli sebanyak 827 orang dan tenaga pengajar/belum mempunyai Jabatan Akademik sebanyak 9976 orang (data dari laman LLDIKTI Wilayah VII pada tanggal 10 bulan April 2020).

Pada tanggal 8 Maret 2020 Lembaga Layanan Pendidikan Tinggi (LLDIKTI) Wilayah VII telah melaksanakan pertemuan online menggunakan aplikasi Zoom yang pesertanya berasal dari Pimpinan Perguruan Tinggi di LLDIKTI Wilayah VII yang diikuti oleh sebanyak 100 peserta/partisipan. Pertemuan tersebut adalah untuk menindaklanjuti Surat Edaran dari Menteri Pendidikan dan Kebudayaan nomor 3 Tahun 2020 tanggal 9 Maret 2010 tentang pencegahan Corona Virus Disease (Covid19) pada satuan pendidikan. Dan surat edaran Plt Dirjen Dikti Nomor : 262/E.E2/KM/2020, tanggan 23 Maret 2020, perihal Pembelajaran Selama Masa Darurat Pandemi COVID-19. Semakin meningkatnya jumlah orang yang terdeteksi positif COVID-19, meluasnya pandemi, dan situasi saat ini mengharuskan kita semua beraktifitas dari rumah (work from home - WfH dan study from home SfH) (Surat Edaran Plt Dirjen Dikti, 2020). Oleh karena itu dalam kondisi darurat ini dan untuk menindaklanjuti Surat Edaran Plt. Dirjen Dikti, LLDIKTI Wilayah VII 
menhimbau kepada PTS sesuai dengan surat edarannya untuk melaksanakan mamajemen proses penyelenggaraan pendidikan tinggi mohon dilakukan dengan pendekatan yang tepat sekaligus membantu upaya untuk menahan laju pertumbuhan wabah.

\section{METODE}

Program Kementerian Pendidikan dan Kebudayaan Republik Indonesia terkait masa pandemi Covid-19 yaitu: Refocusing anggaran yang dapat dianalogikan bahwa untuk perguruan tinggi melakukan refocusing anggaran untuk Memobilisasi relawan mahasiswa dan berpartisipasi layanan call center, screening online, konsultasi online Merdeka belajar dapat digunakan untuk kegiatan mahasiswa menjadi relawan yang dikonversikan menjadi SKS. Siaran pers no 27/sipres/IV/2020 mewabahnya covid-19 menjadi pandemi dunia. Perguruan tinggi diharapkan menerapkan manajemen sistem pembelajaran menggunakan jarak jauh/daring dengan menggunakan SPADA atau menggunakan metode offline/luring. Mahasiswa dapat mengerjakan tugas mandiri/proyek yang berkaitan dengan penanggulangan pandemic covid-19 untuk menambah wawasan keilmuan dan meningkatkan kompetensi mahasiswa. Contoh tugas mandiri: mahasiswa prodi teknik kimia belajar membuat hand sanitizer. Berpartisipasi dalam menekan perkembangan covid-19 dengan pendekatan yang tepat guna.Dirjen dikti menggandeng provider (telkomsel dan XL) untuk memberikan akses gratis melalui IP khusus perguruan tinggi. Masa belajar sesuai SE plt. Dirjen Dikti Kemdikbud Nomor. 302/E.E2/KR/2020 tanggal 31 maret 2020.

Manajemen pembelajaran juga berlaku pada mahasiswa semester akhir yang terancam DO diberi kesempatan perpanjangan 1 semester, Praktek laboratorium dan lapangan dapat dijadwalkan ulang dan digantikan dengan kegiatan lain yang serupa sesuai status dan kondisi PT, dengan harapan nilai tetap keluar di semester sekarang yaitu semester genap tahun akademik semester genap
2019/2020, Penelitian tugas akhir agar diatur metode dan jadwal sesuai status dan kondisi PT. Periode penyelenggaraan kegiatan pembelajaran semester genap 2019/2020 seluruh jenjang program pendidikan dapat disesuaikan dengan kebutuhan dan penyelenggaraan akademik dapat berjalan dengan baik meskipun tidak dapat tercapai $100 \%$. Karya tulis akhir tidak harus pengumpulan data primer di lapangan/laboratorium. Metode dan waktu bisa beragam dan fleksibel sesuai bimbingan dari dosen pembimbing. Jumlah PTS yang melaksanakan kuliah daring dengan adanya Pandemi ini sebagian besar 270 PTS sudah melaksanakan, hal tersebut sesuai dengan laporan yang diterima oleh LLDIKTI Wilayah VII setelah 2 hari permintaan data ke PTS (Surat Edaran Kepala LLDIKTI Wilayah VII, Nomor: 578/Tahun 2020, tanggal 16 Maret 2020 tentang Pencegahan Corona Virus Disease (Covid-19) pada Perguruan Tinggi di Lingkungan LLDIKTI Wilayah VII).

\section{HASIL DAN PEMBAHASAN}

Pada pertemuan secara online menggunakan perangkat Zoom yang bertindak sebagai Tuan Rumah adalah LLDIKTI Wilayah VII yang diikuti oleh sebanyak $\quad 100$ partisipan/pimpinan perguruan tinggi swasta dilingkungan LLDIKTI Wilayah VII, sesuai dengan laporan para partisipan/Pimpinan PTS melalui contak langsung maupun chating secara online semua/100 peserta (100\%) sudah melaksanakan perkuliahan secara daring. Hal-hal yang sudah dilaksanakan oleh beberapa perguruan tinggi swasta di wilayah LLDIKTI VII yang dapat memutus rantai penularan virus Covid-19, antara lain: penyemprotan disenfiktan, Pembagian masker secara gratis, himbauhan seluruh masyarakat agar tidak keluar rumah kalau tidak sangat penting, menghindari kerumunan umum, dengan cara membuat poster baik online maupun ofline. Perguruan tinggi diharapkan melakukan upaya kreatif untuk membantu meringankan mahasiswa terutama dari kelompok ekonomi lemah misalnya subsidi pulsa, logistic melalui mobilisasi alumni untuk mendorong adikadik atau gotong royong dimana yang 
mampu menolong yang tidak mampu. Pandemi ini diperlukan kebijakan yang fleksibel menyesuaikan status dan kondisi pada masing- masing perguruan tinggi sehingga pemimpin perguruan tinggi dapat mengambil kebijakan yang tepat,yaitu menerapan manajemen pembelajaran daring guna untuk memudahkan proses pembelajaran dengan tetap memperhatikan capaian pembelajaran. LLDIKTI Wilayah VII akan sering melakukan vicon tentang manajemen pembelajaran daring untuk mendapatkan informasi dari PTS dan menginformasikan kebijakan baru Kemendikbud. Perguruan Tinggi Swasta dilingkungan LLDIKTI Wilayah VII secara umum telah melaksanakan manajemen pembelajaran secara daring yang disesuaikan kemapmpuan PTS, dengan situasi dan kondisi pada masing-masing daerah, proses pembelajaran berjalan dengan lancar dan UTS telah dilaksanakan dengan baik secara daring. Namun peguruan tinggi yang terkendala dengan akses internet untuk pembelajaran daring, perguruan tinggi melaksanakan pembelajaran secara luring agar proses pembelajaran tetap berjalan dengan baik dan memperhatikan capaian pembelajaran. Beberapa Perguruan Tinggi telah berpartisipasi dalam pandemi covid-19 dengan penggalangan dana, mengedukasi masyarakat antisipasi pandemi covid-19, keringanan biaya ujian kepada mahasiswa dan memberikan bantuan subsidi pulsa kepada mahasiswa, dosen dan staf.

Sebagain besar PTS dilingkungan LLDIKTI Wilayah VII dengan adanya Pandemi Covid-19 ini sudah melaksanakan manajemen perkuliahan secara daring, hal tersebut sesuai dengan laporan yang diterima oleh LLDIKTI Wilayah 318 PT (100\%) sudah melaksanakan kuliah sedaca daring yang disesuaikan dangan kemampuan PT masing-masing. Hasil observasi/laporan salah satu partisipan pertemuan online tersebut, pelaksanaan pembelajaran sistem daring di Lingkungan Perguruan Tinggi Swasta, ada beberapa dosen yang belum terbiasa atau belum membudaya dan juga karena kemampuan dosen untuk mengaplikasikan metode daring bervariasi maka pelaksanaan pembelajaran daring juga ada yang bisa melaksanakan dengan kualitas bagus dan ada juga yang melaksanakan dengan keadaan yang sederhana atau seadanya (berdasarkan hasil survey yang dilaksanakan oleh salah satu partisipan). Kalau sering dilakukan kuliah daring maka para dosen yang belum terampil tentang aplikasi pembelajaran secara daring lamalama akan biasa dan dosen tersebut akan mahir dalam aplikasi daring tersebut. Adapaun fasilitas aplikasi converencing/metode-metode daring yang digunakan dalam pelaksanaan Study From Home (SFH) di PTS LLDIKTI Wilayah VII antara lain: SPAD, Zoom Meeting, Google Class Room, Email, Whatsapp, Telegram, Youtube dan mungkin ada aplikasi lainnya. Dari hasil Obsevari dilapangan/peserta partisipan pertemuan secara online tersebut kami sampaikan bahwa sebagian besar PTS di lingkungan LLDIKTI Wilayah VII 318 PTS (100\%) sudah melaksanakan manajemen Perkuliahan Daring. Menurut hemat kami selama masa penanggulangan penularan Covid-19, walaupun semua kegiatan itu dilakukan di rumah atau dengan metode manajemen daring sehingga program pepemerintah untuk memutus rantai penularan covid-19 bisa sukses dan berjalan dengan baik. Sedangakan proses pembelajaran di perguruan tinggi tetap berjalan dan capaian pembelajaran tetap terpenuhi.

\section{SIMPULAN}

Covid-19 harus diputus mata rantai penularannya dengan cara: berdiam diri di rumah, menghindari semaksimal mungkin terjadinya penggerombolan/kerumunan masa, oleh karena itu sangat tepat sekali sesuai dengan edaran menteri Pendidikan dan Kebudayaan agar civitas akademika di Perguruan Tinggi agar melaksanakan Study From Home (SFH)/Perkuliahan secara daring. Dengan adanya perkuliahan secara daring ini capaian pembelajaran harus terpenuni. Semua PTS dilingkungan LLDIKTI Wilayah VII sudah melaksanakan manajemen perkuliah secara daring sesuai SE Mendikbud nomor: 3 tahun 2020 tentang pencegahan corona virus disease (Covid-19) pada satuan pendidikan. Perkuliahan daring ada beberapa PTS yang sudah melaksanakan sebelum ada himbauan dari pemerintah 
terkait dengan adanya wabah Covid-19. Dengan adanya manajemen perkuliahan

\section{DAFTAR PUSTAKA}

Khan, B.H., Web Based Instruction, Educational Technology Publications. New Jersey: Englewood Cliffs, 1997).

Bates, T., The Impact of Technological Change on Open and Distance Learning. Distance Education, 1997.

Tung, Khoe Yao, Pendidikan dan Riset di Internet, Jakarta: Dinastindo, 2000.

Surat Edaran dari Menteri Pendidikan dan Kebudayaan nomor 3 Tahun 2020 tanggal 9 Maret 2010.

Arikunto, Suharsimi, Prosedur Penelitian: Suatu Pendekatan Praktik, Jakarta : Rineka Cipta, 2006.

Faisal, Sanafiah, Format-format Penelitian, Jakarta: PT. Raja Grafindo Persada, 2001. Kementerian Pendidikan dan Kebudayaan RI, Panduan Pengembangan dan Penyelenggaraan KDITT, Jakarta: Kemendikbud, 2014.

Formulasi Model Perkuliahan Daring Sebagai Upaya Menekan Disparitas Kualitas Perguruan Tinggi (Studi terhadap Website pditt.belajar.kemdikbud.go.id)

Mokhamad Iklil Mustofa1, Muhammad Chodzirin $^{2}$, Lina Sayekti ${ }^{3} 1,2,3$ Universitas Islam Negeri Walisongo Semarang Walisongo Journal of Information Technology, Vol. 1 No. 2 (2019): 151-160 DOI : http://dx.doi.org/10.21580/wjit.2019.1. 2.4067Copyright (c) 2019 WJIT: Walisongo Journal of Information Technology. daring ini perkuliahan tetap berjalan dan capaian pembelajaran tetap terpenuhi.

Surat Edaran Kepala LLDIKTI Wilayah VII, Nomor: 676/LL7/AK/2020, tanggal 3 Maret 2020, tentang Kebijakan Perguruan Tinggi terkait implikasi COVID-19.

Surat Edaran Kepala LLDIKTI Wilayah VII, Nomor: 578/Tahun 2020, tanggal 16 Maret 2020 tentang Pencegahan Corona Virus Disease (Covid-19) pada Perguruan Tinggi di Lingkungan LLDIKTI Wilayah VII.

Surat Edaran Plt Dirjen Dikti Nomor: 1239/E.E2/DT/2020 Tanggal 17 Maret 2020. Perihal : Permintaan Sharing dengan Membuka Akses Pembelajaran Daring.

Surat Edaran Plt. Dirjen Dikti Kementerian Pendidikan dan Kebudayaan Nomor: 262/E.E2/KM/2020 tanggal 23 Maret 2020, tentang Pembelajaran Selama Masa Darurat Pandemi Covid-19.

Surat Edaran Plt Dirjen Dikti Kementerian Pendidikan dan Kebudayaan Republik Indonesia Nomor: 302/E.E2/KR/2020 tanggal 31 Maret 2020, tentang Masa Belajar Penyelenggaraan Program Pendidikan. 